\title{
Downregulation of peroxisome proliferator-activated receptor $\alpha$ and its coactivators in liver and skeletal muscle mediates the metabolic adaptations during lactation in mice
}

\author{
Anke Gutgesell, Robert Ringseis ${ }^{1}$, Eileen Schmidt, Corinna Brandsch, \\ Gabriele I Stangl and Klaus Eder ${ }^{1}$
}

Institute of Agricultural and Nutritional Sciences, Martin-Luther-Universität Halle-Wittenberg, Von-Danckelmann-Platz 2, D-06120 Halle (Saale), Germany

${ }^{1}$ Chair of Animal Nutrition, Center of Life and Food Sciences Weihenstephan, Technische Universität München, Hochfeldweg 1, D-85350 Freising, Germany

(Correspondence should be addressed to K Eder; Email: k.eder@wzw.tum.de)

\begin{abstract}
Previous studies have shown that genes involved in fatty acid uptake, fatty acid oxidation, and thermogenesis are downregulated in liver and skeletal muscle of rats during lactation. However, biochemical mechanisms underlying these important metabolic adaptations during lactation have not yet been elucidated. As all these genes are transcriptionally regulated by peroxisome proliferator-activated receptor $\alpha(P p a r \alpha)$, we hypothesized that their downregulation is mediated by a suppression of Ppar $\alpha$ during lactation. In order to investigate this hypothesis, we performed an experiment with lactating and nonlactating Ppar $\alpha$ knockout and corresponding wild-type mice. In wild-type mice, lactation led to a considerable downregulation of Ppar $\alpha$, Pparcoactivators Pgc1 $\alpha$ and Pgc1 $\beta$, and Ppar $\alpha$ target genes involved in fatty acid uptake, fatty acid oxidation, and thermogenesis in liver and skeletal muscle $(P<0.05)$. Ppar $\alpha$ knockout mice had generally a lower expression of all these Ppar $\alpha$ target genes in liver and skeletal muscle. However, in those mice, lactation did not lower the expression of genes involved in fatty acid utilization and thermogenesis in liver and skeletal muscle. Expression levels of Ppar $\alpha$ target genes in lactating wild-type mice were similar than in lactating or nonlactating Ppar $\alpha$ knockout mice. In conclusion, the present findings suggest that downregulation of Ppar $\alpha$ and its coactivators in tissues with high rates of fatty acid catabolism is responsible for the reduced utilization of fatty acids in liver and skeletal muscle and the reduced thermogenesis occurring in the lactating animal, which aim to conserve energy and metabolic substrates for milk production in the mammary gland.
\end{abstract}

Journal of Molecular Endocrinology (2009) 43, 241-250

\section{Introduction}

Lactation is a physiological state characterized by a dramatic increase in the energy and nutrient requirement of the organism for milk production. This demand is usually met by a markedly increased food intake and by the utilization of energy stores. In addition, several metabolic adaptations develop in the lactating animal aiming to conserve energy and metabolic substrates for milk production in the mammary gland (Trayhurn et al. 1982, Williamson 1986, Dewey 1997, Smith \& Grove 2002). Recently, it has been shown that downregulation of uncoupling proteins $(U c p) 1$ and 3 in brown adipose tissue and of $U_{c p 3}$ in skeletal muscle, leading to a decrease in metabolic fuel oxidation and thermogenesis, contributes to these metabolic adaptations during lactation (Trayhurn et al. 1982, Pedraza et al. 2000, 2001, Xiao et al. 2004a). Furthermore, expression of proteins involved in uptake and oxidation of fatty acids in skeletal muscle (Xiao et al. 2004b) as well as the rates of fatty acid oxidation and ketogenesis in the liver (Whitelaw \& Williamson 1977) are reduced during lactation, effects that help to spare fatty acids for milk production in the mammary gland. Both $U c p$ and proteins involved in fatty acid uptake and oxidation are transcriptionally regulated by peroxisome proliferatoractivated receptor $\alpha$ (Ppar $\alpha$; Bruns et al. 1999, Barbera et al. 2000, Young et al. 2001, Mandard et al. 2004). Ppara is a ligand-activated transcription factor, which is abundantly expressed in tissues with high rates of fatty acid oxidation, such as liver and skeletal muscle, and its physiologic role lies in the mediation of metabolic responses to fasting (Schoonjans et al. 1997, Leone et al. 1999, Mandard et al. 2004). Upon activation by either nonesterified fatty acids (NEFA) released from adipose tissue and taken up into tissues or exogenous ligands (diet-derived fatty acids or fibrates), Ppard upregulates genes involved in all aspects of fatty acid catabolism including cellular fatty acid uptake and transport, mitochondrial and peroxisomal fatty acid oxidation, as well as ketogenesis (Mandard et al. 2004). We have

DOI: 10.1677/JME-09-0064 Online version via http://www.endocrinology-journals.org 
recently observed that lactating rats have reduced mRNA concentrations of Ppar $\alpha$ and Ppar $\alpha$-regulated genes involved in fatty acid utilization in the liver compared with nonlactating rats (Gutgesell et al. 2009). This finding suggested that downregulation of genes involved in fatty acid uptake and oxidation as well as $U c p$ during lactation is mediated by suppression of Ppard.

The aim of the present study was to test the hypothesis that downregulation of Ppara mediates the reduced expression of genes involved in fatty acid uptake and $\beta$-oxidation in tissues with high rates of fatty acid utilization such as liver and skeletal muscle, which favors the availability of fatty acids for milk triacylglycerol (TAG) production in the mammary gland. For that purpose, we performed an experiment with Ppard knockout and corresponding wild-type mice, and studied the influence of lactation on the expression of Ppard and selected Ppara-responsive genes involved in fatty acid uptake $\left(F a b p_{p m}\right.$ and Fatp), fatty acid oxidation (Cpt I, Cyp4a10 and Mcad), and thermogenesis (Ucp3) in liver and skeletal muscle respectively. It has been shown that the transcriptional activity of Ppar is enhanced by several coactivators, including Ppary coactivator $(P g c) 1 \alpha$ and $1 \beta$. These coactivators are required for the ability of Ppar to increase gene transcription to the maximum (Yu \& Reddy 2007). In order to study whether lactation influences the expression of these coactivators, we also determined the expression of $P g c 1 \alpha$ and $P g c 1 \beta$ in liver and skeletal muscle.

During lactation, an increased flow of NEFA, originating from hydrolysis of TAG by hormonesensitive lipase in adipose tissue into the mammary gland for milk production, is observed, whereas uptake of fatty acids by lipoprotein lipase $(L p l)$ from TAG-rich lipoproteins such as chylomicrons and very low-density lipoproteins into adipose tissue is reduced during lactation (Williamson 1986). The uptake of both fatty acids released by $L p l$ from TAG-rich lipoproteins and albumin-bound NEFA in the plasma released from adipose tissue into the mammary gland is mediated by fatty acid transporters, and is an important source for milk TAG synthesis. To obtain information about alterations in the uptake of fatty acids into the mammary gland during lactation, we also determined expression of fatty acid transporters and $L p l$ in the mammary gland as well as TAG concentrations in plasma.

\section{Materials and methods}

\section{Animal experiment}

The animal experiment was carried out with female Ppard knockout mice (129S4/SvJae-Ppara $\left.{ }^{\operatorname{tm} 1 \mathrm{Gonz}} / \mathrm{J}\right)$ and corresponding wild-type mice (129S1/SvImJ) obtained from Jackson Laboratory (Bar Harbor, ME, USA). They were kept in Macrolon cages in a room maintained with controlled temperature $\left(23 \pm 1{ }^{\circ} \mathrm{C}\right)$, humidity $(50-60 \%)$, and lighting $(0600$ to $1800 \mathrm{~h})$. All animals were fed a commercial standard diet for rodents (Altromin $\mathrm{GmbH}$, Lage, Germany). The standard diet was nutritionally adequate for lactating mice according to the recommendations of American Society for Nutritional Sciences (ASNS) (Reeves et al. 1993), and contained $11.9 \mathrm{MJ} / \mathrm{kg}$ metabolizable energy. The composition of the standard diet was ( $\mathrm{g} / \mathrm{kg}$ diet $)$ : crude protein $(19 \cdot 0)$, crude fat $(4 \cdot 0)$, crude fiber $(6 \cdot 0)$, crude ash $(7 \cdot 0)$, and nitrogen-free extracts $(53.0)$ (Altromin). Water was available ad libitum from nipple drinkers. All experimental procedures described followed established guidelines for the care and

Table 1 Characteristics of the primers used for RT-PCR analysis with real-time detection

Forward primer (from $5^{\prime}$ to $3^{\prime}$ )

\section{Gene}

$\begin{array}{ll}\beta \text {-actin } & \text { ACGGCCAGGTCATCACTATTG } \\ \text { Cyp18 } & \text { GTGGTCTTTGGGAAGGTGAA } \\ \text { Cyp4a10 } & \text { TGAGGGAGAGCTGGAAAAGA } \\ \text { Fabp pm } & \text { CCAGAAAGGGAAGGACATCA } \\ \text { Fas } & \text { TGGGTTCTAGCCAGCAGAGT } \\ \text { Fat/Cd36 } & \text { GAGCAACTGGTGGATGGTTT } \\ \text { Fatp } & \text { TGCTTTGGTTTCTGGGACTT } \\ \text { Gapdh } & \text { AACGACCCCTTCATTGAC } \\ \text { l-Cpt I } & \text { CCAGGCTACAGTGGGACATT } \\ \text { Lpl } & \text { GGGCTCTGCCTGAGTTGTAG } \\ \text { Mcad } & \text { AGGTTTCAAGATCGCAATGG } \\ \text { m-Cpt I } & \text { GTCGCTTCTTCAAGGTCTGG } \\ \text { Pgc1 } 1 & \text { AAACTTGCTAGCGGTCCTCA } \\ \text { Pgc1 } \beta & \text { AACCCAACCAGTCTCACAGG } \\ \text { Ppar } \alpha & \text { CGGGAAAGACCAGCAACAAC } \\ \text { Ucp3 } & \text { CCACACTT CCTCCTGCTCTC }\end{array}$

Reverse primer $\left(5^{\prime}-3^{\prime}\right)$

CACAGGATTCCATACCCAAGAAG TTACAGGACATTGCGAGCAG CTGTTGGTGATCAGGGTGTG GTCTCCAGTTCGCACTCCTC ACCACCAGAGACCGTTATGC GCAGAATCAAGGGAGAGCAC GCTCTAGCCGAACACGAATC TCCACGACATACTCAGCAC GAACTTGCCCATGTCCTTGT AGAAATTTCGAAGGCCTGGT CTCCTTGGTGCTCCACTAGC AAGAAAGCAGCACGTTCGAT TGTTGACAAATGCTCTTC TGCTGCTGTCCTCAAATACG TGGCAGTGGAAGAATCG GTATAGGGCGCTCAAATGGA

PCR product
size (bp)
size (bp)

NCBI GenBank

\section{CBI GenBank}

NM_007393

NM_008907

NM_010011

NM_017399

NM_007988

NM_007643

NM_11977

XM_001476707

NM_013495

NM_008509

NM_007382

NM_009948

NM_008904

NM_133249

NM_011144

NM_009464 
handling of laboratory animals (UFAW 1999, Society for Endocrinology's guidelines on the use of animals, URL: http://www.endocrinology-journals.org/misc/ use_of_animals.dtl) and were approved by the council of Saxony-Anhalt.

At 14 weeks of age, the mice were mated by housing two female mice with one male mouse (129S1/SvImJ) for 6 days. At the day of parturition, designated as day 1 of lactation, wild-type mice $(n=10)$ and Ppara knockout mice $(n=14)$ were randomly assigned to two groups. In one group of the wild-type and Ppara knockout mice, all pups were removed (without litter), whereas in the other group litters were adjusted to six pups per dam (with litter). During pregnancy and lactation, female mice were kept individually in single cages, and diets fed ad libitum. Feed consumption was measured every day by determining the weight of the remaining diet at the day after feed administration. At day 15 of lactation, dams received the last dose of the diet at the beginning of the light cycle $(0600 \mathrm{~h})$ and were killed $4 \mathrm{~h}$ later at $1000 \mathrm{~h}$ by decapitation under light anesthesia with diethyl ether. Animals were killed in the nonfasted state to prevent fasting-induced Ppara activation.

\section{Sample collection}

Blood was collected into heparinized polyethylene tubes (Sarstedt, Nürnberg, Germany). Plasma was obtained by centrifugation of the blood $(1100 \mathrm{~g}$; $10 \mathrm{~min} ; 4^{\circ} \mathrm{C}$ ) and stored at $-20^{\circ} \mathrm{C}$. Liver, mammary gland, and skeletal muscle were excised, immediately shock frozen with liquid nitrogen, and stored at $-80^{\circ} \mathrm{C}$ pending analysis.

\section{Lipid analysis}

Plasma TAG concentrations were measured using reagent kits obtained from Merck Eurolab (Ref. 113009990314) according to the manufacturer's protocol.

\section{RNA isolation and RT-PCR with real-time detection}

Total RNA was isolated from the liver, mammary gland, and skeletal muscle (M. semitendinosus) using Trizol reagent (Invitrogen) according to the manufacturer's protocol. RNA concentration and purity were estimated from the optical density at 260 and $280 \mathrm{~nm}$ (SpectraFluor Plus, Tecan, Crailsheim, Germany). Synthesis of cDNA and determination of mRNA abundance by RT-PCR with real-time detection (Rotorgene 2000, Corbett Research, Mortlake, New South Wales, Australia) using Sybr Green I were performed as recently described in detail (Ringseis et al. 2007c).
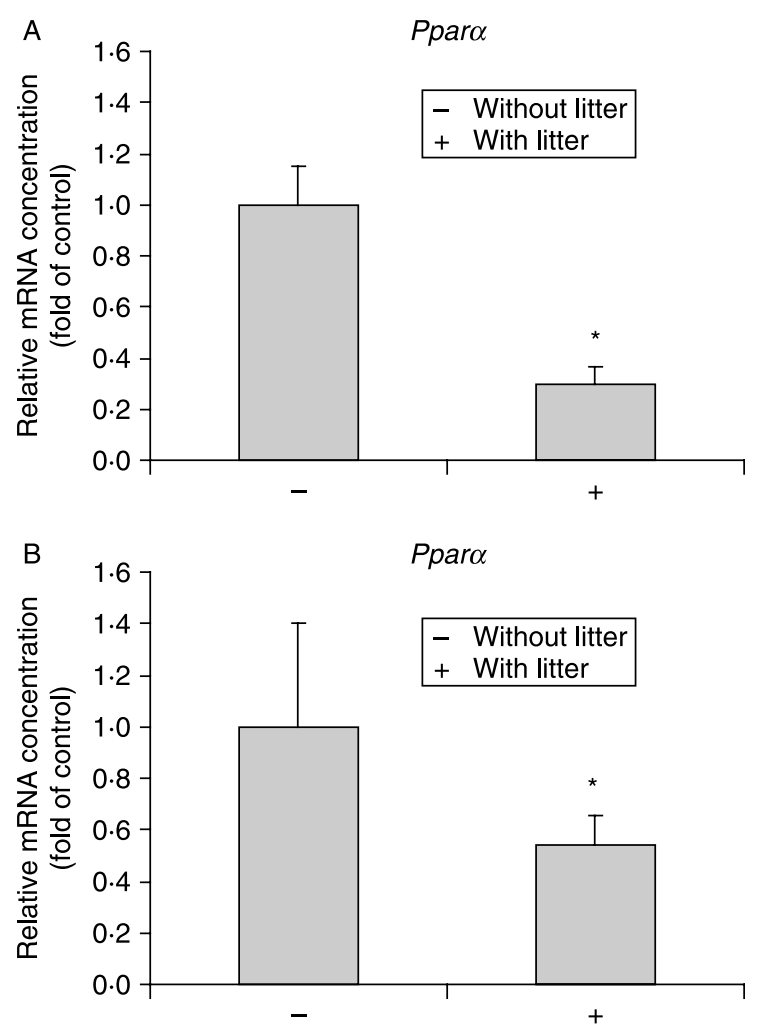

Figure 1 Relative mRNA concentrations of Ppara in the liver (A) and skeletal muscle (B) of wild-type mice, whose litters were either removed (without litter) or adjusted to 6 pups/dam (with litter) immediately after birth, at day 15 of lactation. Bars represent means \pm S.E.M. for $n=5$. *Indicates a significant difference from 'without' litter group. $P<0.05$.

Relative quantification of mRNA concentrations was performed using the $\Delta \Delta C_{\mathrm{t}}$ method (Pfaffl 2001). Threshold cycle $\left(C_{\mathrm{t}}\right)$ values were obtained using Rotorgene Software 5.0 (Corbett Research). The housekeeping genes Gapdh (liver), $\beta$-actin (skeletal muscle), and Cyp18 (mammary gland) were used for normalization. Different housekeeping genes were used in the various tissues, because none of the housekeeping genes tested served as an appropriate reference gene in all tissues. The existence of a single PCR product of the expected length was guaranteed by melting curve analysis and $1 \%$ agarose gel electrophoresis. Relative mRNA concentrations are expressed as fold of mRNA concentration of the wild-type without litter group. Characteristics of the primers (Eurofins MWG Operon, Ebersberg, Germany) used for RT-PCR with real-time detection are shown in Table 1.

\section{Statistical analysis}

Data were analyzed using the Minitab Statistical Software (Minitab Rel. 15, State College, PA, USA). Treatment effects were analyzed by two-way ANOVA 

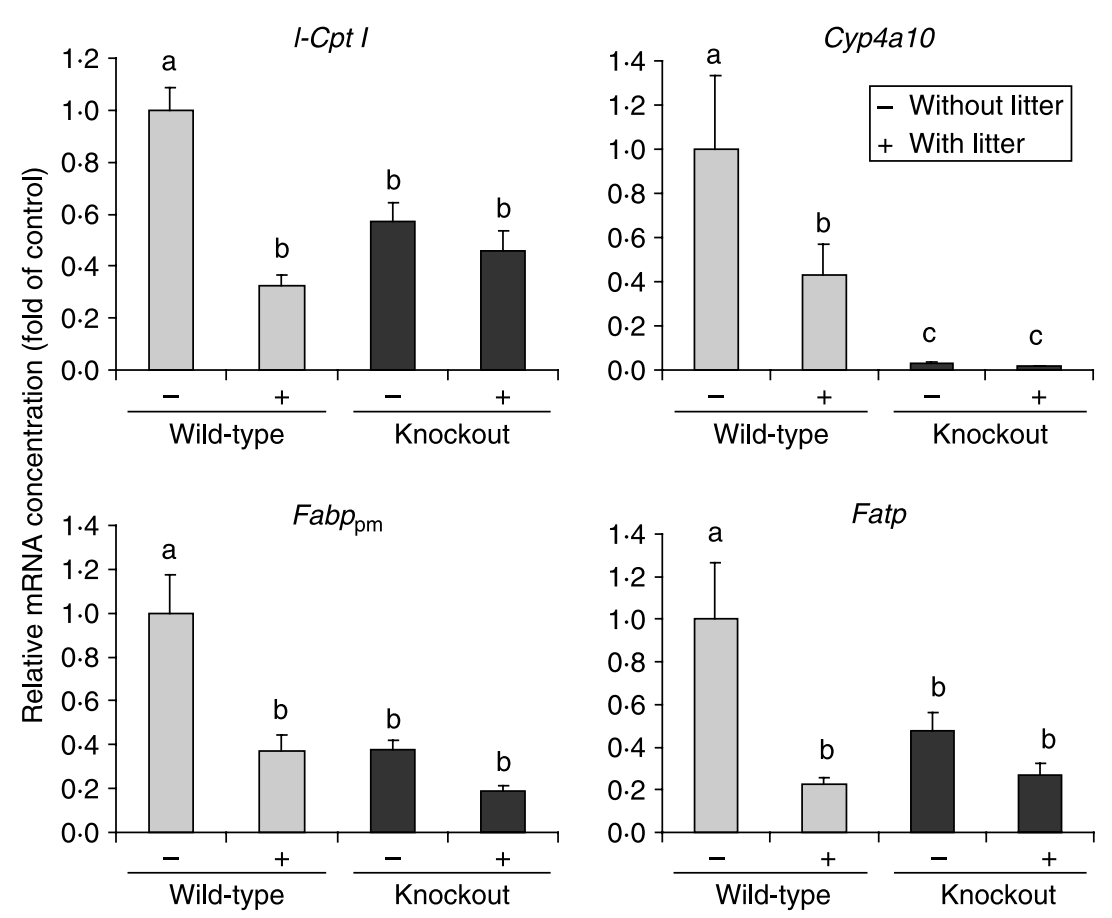

Figure 2 Relative mRNA concentrations of the Ppard target genes I-Cpt I, Cyp4a10, $F a b p_{p m}$, and Fatp in the liver of lactating wild-type and lactating Ppar knockout mice, whose litters were either removed (without litter) or adjusted to 6 pups/dam (with litter) immediately after birth, at day 15 of lactation. Bars represent means \pm S.E.M. for $n=5$ in wild-type mice and $n=7$ in Ppar $\alpha$ knockout mice. Bars without a common letter (a-c) differ, $P<0.05$. Significant effects $(P<0.05)$ from two-way ANOVA: $I-C p t l$ : litter, genotype, and litter $\times$ genotype; Cyp4a10: litter, genotype, and litter $\times$ genotype; Fabp $p_{p m}$ : litter, genotype, and litter $\times$ genotype; Fatp: litter, genotype, and litter $\times$ genotype.

with classification factors being litter, genotype, and the interaction of litter and genotype. For significant $F$-values, means were compared by Fisher's multiple range test. Means were considered significantly different for $P<0 \cdot 05$. Data presented in the text are shown as means \pm s.E.M.

\section{Results}

\section{Food intake, body weights of dams, and weights of litters}

Dams with litters consumed more food per day than those without litters, irrespective of genotype (wild-type mice without litter: $2 \cdot 0 \pm 0 \cdot 2 \mathrm{~g} / \mathrm{d}$; wild-type mice with litter: $7 \cdot 7 \pm 0.7 \mathrm{~g} / \mathrm{d}$; Ppar $\alpha$ knockout mice without litter: $2 \cdot 1 \pm 0 \cdot 2 \mathrm{~g} / \mathrm{d}$; Ppara knockout mice with litter: $7 \cdot 9 \pm 1 \cdot 0 \mathrm{~g} / \mathrm{d} ; P<0 \cdot 05)$. Body weights of dams at day 1 of lactation did not differ between groups (wildtype mice without litter: $22 \cdot 2 \pm 0 \cdot 6 \mathrm{~g}$; wild-type mice with litter: $22 \cdot 1 \pm 0.9 \mathrm{~g}$; Ppara knockout mice without litter: $22.7 \pm 1.3 \mathrm{~g}$; Ppara knockout mice with litter: $23 \cdot 7 \pm 2 \cdot 2 \mathrm{~g})$. However, body weights at day 15 of lactation were higher in dams with litters than in those without litters, irrespective of the genotype (wild-type mice without litter: $20 \cdot 8 \pm 0 \cdot 6 \mathrm{~g}$; wild-type mice with litter: $26.0 \pm 0.7 \mathrm{~g}$; Ppar $\alpha$ knockout mice without litter: $20 \cdot 1 \pm 0.9 \mathrm{~g}$; Ppara knockout mice with litter: $26 \cdot 1 \pm 2 \cdot 1 \mathrm{~g} ; P<0 \cdot 05)$. Litter weights of dams of both genotypes did not differ either at day 1 or at day 15 of lactation (day 1 of lactation: wild-type mice: $11 \cdot 8 \pm 1 \cdot 0 \mathrm{~g}$; Ppar $\alpha$ knockout mice: $11 \cdot 2 \pm 1 \cdot 1 \mathrm{~g}$; day 15 of lactation: wild-type mice: $43 \cdot 5 \pm 2 \cdot 1 \mathrm{~g}$; Ppar $\alpha$ knockout mice: $44 \cdot 8 \pm 2 \cdot 2 \mathrm{~g})$.

\section{TAG concentrations in plasma}

TAG concentrations in plasma were influenced by the factors litter and genotype $(P<0 \cdot 05)$; mice with litters had lower concentrations of TAG in plasma than those without litters, irrespective of the genotype; Ppara knockout mice had higher TAG concentrations in plasma than wild-type mice (wild-type mice without litter: $0 \cdot 61 \pm 0 \cdot 10 \mathrm{mmol} / \mathrm{l}$; wild-type mice with litter: $0.39 \pm 0.02 \mathrm{mmol} / \mathrm{l} ;$ Ppara knockout mice without litter: $0.90 \pm 0.10 \mathrm{mmol} / \mathrm{l}$; Ppar $\alpha$ knockout mice with litter: $0 \cdot 69 \pm 0.09 \mathrm{mmol} / \mathrm{l})$. 

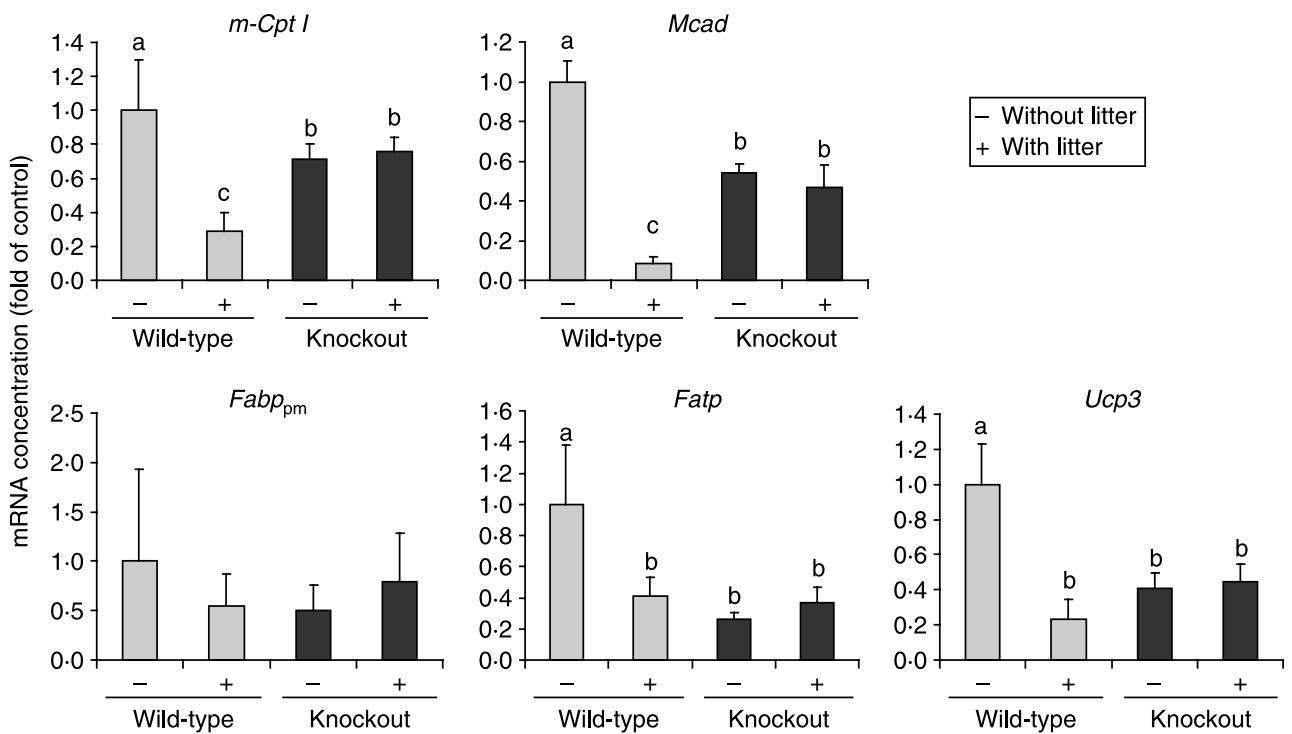

Figure 3 Relative mRNA concentrations of the Ppar $\alpha$ target genes $m$-Cpt I, Mcad, Fabp ${ }_{p m}$, Fatp, and Ucp3 in the skeletal muscle of lactating wild-type and lactating Ppar $\alpha$ knockout mice, whose litters were either removed (without litter) or adjusted to 6 pups/dam (with litter) immediately after birth, at day 15 of lactation. Bars represent means \pm S.E.M. for $n=5$ in wild-type mice and $n=7$ in Ppar $\alpha$ knockout mice. Bars without a common letter $(\mathrm{a}-\mathrm{c})$ differ, $P<0.05$. Significant effects $(P<0.05)$ from two-way ANOVA: $m-C p t$ : litter and litter $\times$ genotype; Mcad: litter and litter $\times$ genotype; Fatp: genotype and litter $\times$ genotype; Ucp3: litter and litter $\times$ genotype.

\section{Expression of Ppara in liver and skeletal muscle}

Wild-type mice with litters had markedly lower relative mRNA concentrations of Ppara in liver and skeletal muscle than wild-type mice without litters $(P<0 \cdot 05 ;$ Fig. 1$)$.

\section{Expression of Ppara target genes in the liver}

Wild-type mice with litters had markedly lower relative mRNA concentrations of l-Cpt I, Cyp4A10, Fatp, and $F a b p_{p m}$ in the liver than wild-type mice without litters $(P<0 \cdot 05$; Fig. 2). Relative mRNA concentrations of all these genes in the liver were lower in Ppar $\alpha$ knockout mice with and without litters than in wild-type mice with litters $(P<0.05$; Fig. 2); however, relative mRNA concentrations of these genes in the liver did not differ between Ppara knockout mice with litters and those without litters (Fig. 2).

\section{Expression of Ppara target genes in skeletal muscle}

In skeletal muscle, relative mRNA concentrations of $m$-Cpt I, Mcad, Fatp, and Ucp3 were lower in wild-type mice with litters compared with wild-type mice whose litters were removed $(P<0 \cdot 05 ;$ Fig. 3). In contrast, relative mRNA concentrations of these genes did not differ between Ppara knockout mice with litters and $P p a r \alpha$ knockout mice without litters (Fig. 3). The relative mRNA concentrations of $m$-Cpt I, Mcad, Fatp, and $U c p 3$ in skeletal muscle were lower in Ppard knockout mice with and without litters than in wildtype mice without litters $(P<0 \cdot 05$; Fig. 3). Unexpectedly, relative mRNA concentrations of $m$-Cpt I and Mcad in skeletal muscle in wild-type mice with litters were even lower than in Ppara knockout mice with and without litters $(P<0 \cdot 05$; Fig. 3). The relative mRNA concentration of $\mathrm{Fabp}_{p m}$ in skeletal muscle did not differ between the four groups of mice (Fig. 3).

\section{Expression of Ppar coactivators Pgc1 $\alpha$ and Pgc1 $\beta$ in liver and skeletal muscle}

In liver and skeletal muscle, relative mRNA concentrations of $P g c 1 \alpha$ and $P g c 1 \beta$ were lower in wild-type mice with litters compared with wild-type mice whose litters were removed $(P<0 \cdot 05 ;$ Fig. 4$)$. In contrast, relative mRNA concentrations of Pgcl $\alpha$ and $P g c 1 \beta$ in liver and skeletal muscle did not differ between Ppar $\alpha$ knockout mice with litters and Ppar $\alpha$ knockout mice without litters (Fig. 4). However, whereas relative mRNA concentrations of Pgc1 $\alpha$ and $P g c 1 \beta$ in liver were lower in Ppard knockout mice with and without litters than in wild-type mice without litters $(P<0 \cdot 05$; Fig. 4), relative mRNA concentrations of these genes in skeletal muscle did not differ between wild-type mice without litters and Ppard knockout mice with and without litters (Fig. 4). 


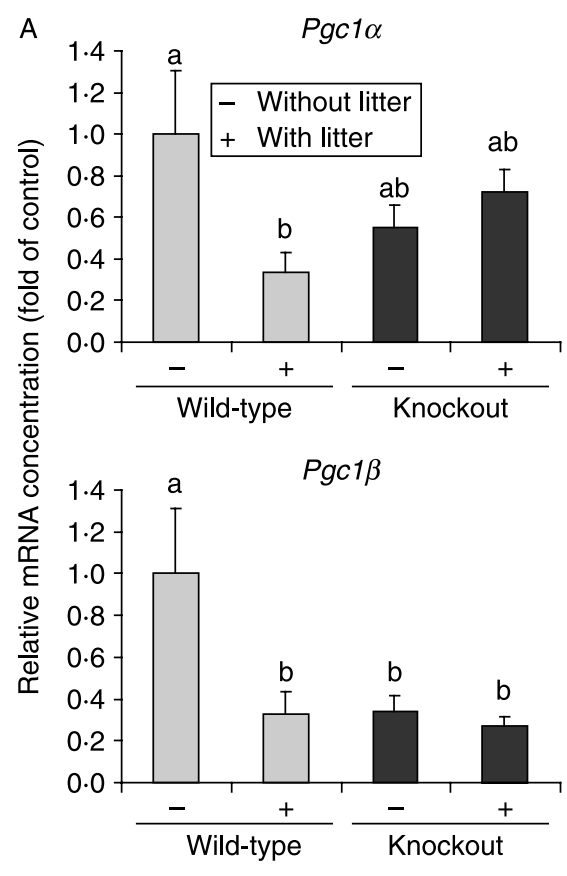

B
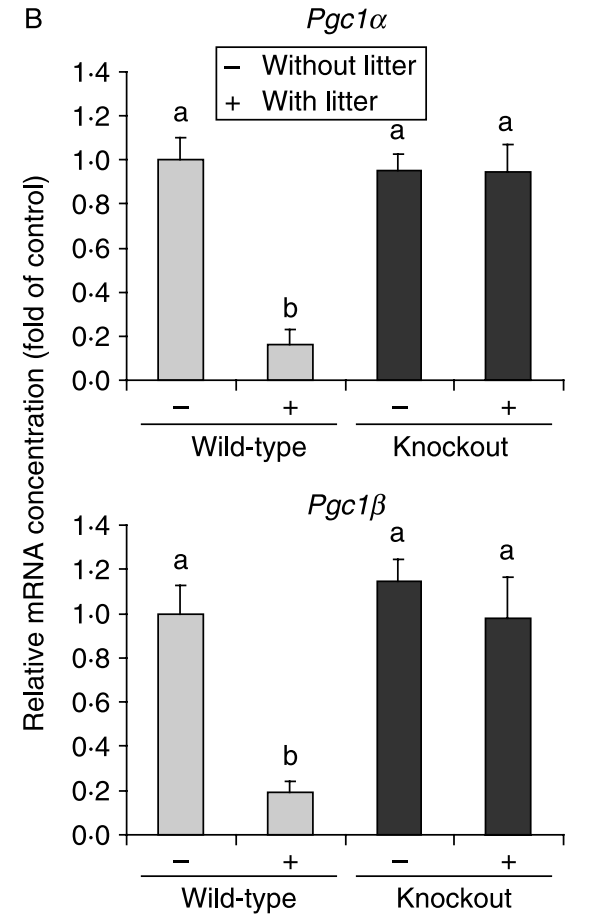

Figure 4 Relative mRNA concentrations of $P g c 1 \alpha$ and $P g c 1 \beta$ in liver (A) and skeletal muscle (B) of lactating wild-type and lactating Ppar $\alpha$ knockout mice, whose litters were either removed (without litter) or adjusted to 6 pups/dam (with litter) immediately after birth, at day 15 of lactation. Bars represent means \pm S.E.M. for $n=5$ in wild-type mice and $n=7$ in Ppara knockout mice. Bars without a common letter (a-b) differ, $P<0.05$. Significant effects $(P<0.05)$ from two-way ANOVA: $P g c 1 \alpha$ liver: litter and litter $\times$ genotype; $P g c 1 \beta$ liver: litter, genotype and litter $\times$ genotype; Pgc1 $\alpha$ skeletal muscle: litter and litter $\times$ genotype; $P g c 1 \beta$ skeletal muscle: litter and litter $\times$ genotype.
Expression of fatty acid transporters, $L p l$, and fatty acid synthase in the mammary gland of mice

Wild-type mice with litters had markedly higher mRNA concentrations of Fat/Cd36, Fatp, Lpl, and fatty acid synthase (Fas) in the mammary gland than wild-type mice without litters $(P<0 \cdot 05$; Fig. 5). In Ppar $\alpha$ knockout mice, the mRNA concentrations of these genes were also higher in the mammary gland of dams with litters than in those without litters $(P<0 \cdot 05$; Fig. 5$)$.

\section{Discussion}

The aim of the present study was to test the hypothesis that downregulation of Pparc in tissues with high rates of fatty acid catabolism (liver and skeletal muscle) is responsible for the metabolic adaptations occurring in the lactating animal, such as decreased fatty acid oxidation and diminished thermogenesis (Zammit 1980, Pedraza et al. 2000, 2001, Xiao et al. 2004a,b). Herein, we could clearly demonstrate for the first time that downregulation of Ppar $\alpha$ and Ppar $\alpha$ target genes involved in fatty acid uptake $\left(F a b p_{p m}\right.$ and Fatp), fatty acid oxidation (Cpt I, Cyp4a10, and Mcad), and thermogenesis $(U c p 3)$ occurs only in tissues of lactating wildtype mice. In Ppar $\alpha$ knockout mice, in contrast, lactation did not result in a reduced expression of Ppard and Ppar target genes in these tissues. These findings strongly indicate that the metabolic adaptations in the lactating animal (Zammit 1980, Pedraza et al. 2000, 2001, Xiao et al. 2004a,b) are mediated by the diminished expression of Ppara in liver and skeletal muscle. As expected, expression levels of Ppara target genes were markedly lower in liver and skeletal muscle of Ppar $\alpha$ knockout mice than in those of nonlactating wild-type mice. In this regard, it is, however, noteworthy that Ppard target genes, with the exception of $m$-Cpt I and Mcad in skeletal muscle, were expressed in tissues of Ppara knockout mice at levels comparable with those of lactating wild-type mice. This indicates that lactation in wild-type mice causes a similar reduction in the expression of Ppar $\alpha$ target genes as disruption of Ppar $\alpha$ expression.

Although Ppara is clearly an important transcription factor in regulating the expression of genes involved in fatty acid oxidation, the observation that the mRNA levels of $m$-Cpt I and Mcad in skeletal muscle were even stronger reduced by lactation than by the Ppard knockout implies that also other Ppara-independent mechanisms might be involved. As lactating wild-type mice had lower mRNA concentrations of Pgcl $\alpha$ and $P g c 1 \beta$, which are required for maximal transcriptional activity of Ppar (Yu \& Reddy 2007, Feingold et al. 2008), in liver and skeletal muscle than their nonlactating counterparts, we suggest that a reduced expression of 


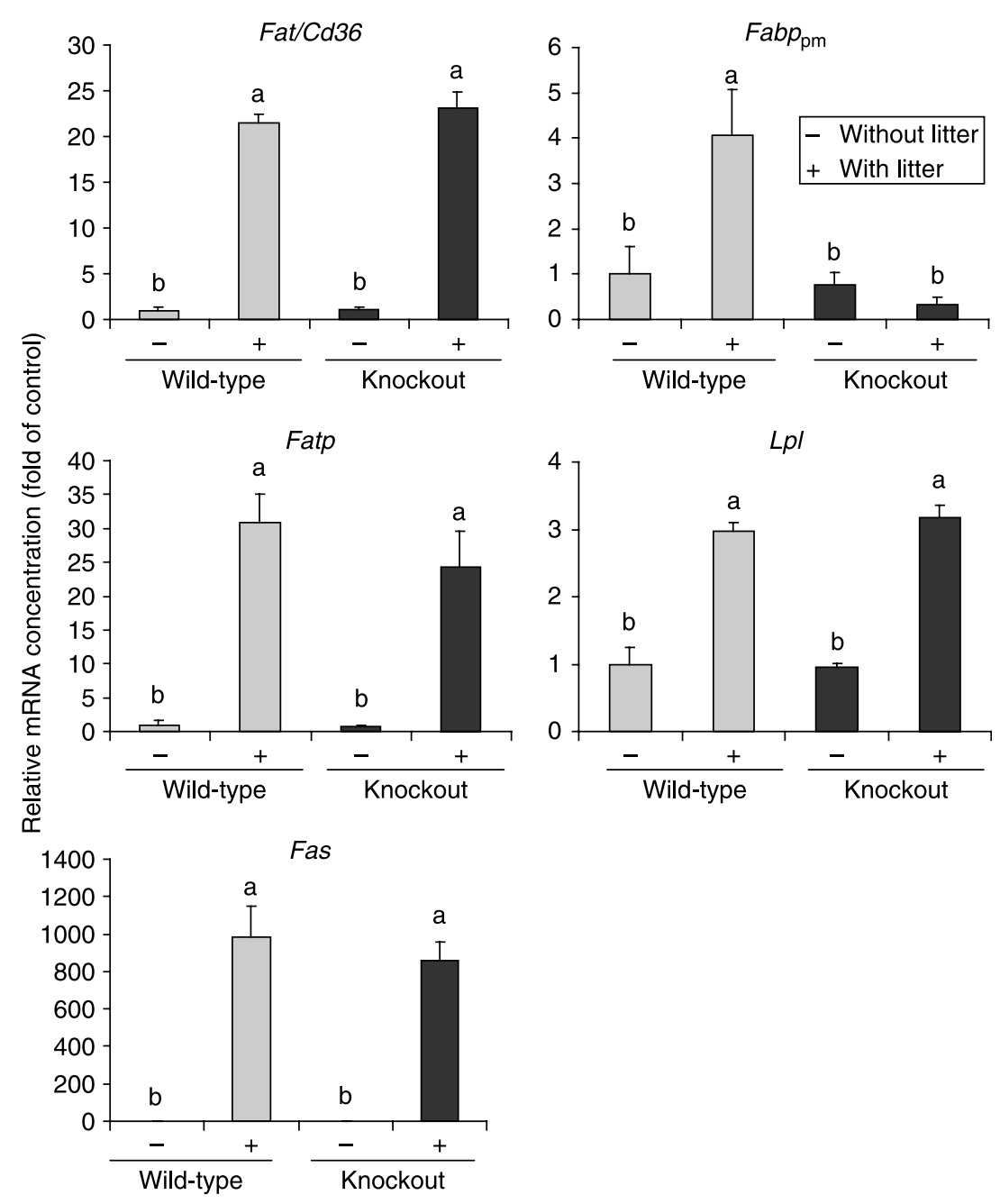

Figure 5 Relative mRNA concentrations of Fat/Cd36, Fabp $p_{p m}$, Fatp, Lpl, and Fas in the mammary gland of lactating wild-type and lactating Ppar $\alpha$ knockout mice, whose litters were either removed (without litter) or adjusted to 6 pups/dam (with litter) immediately after birth, at day 15 of lactation. Bars represent means \pm S.E.M. for $n=5$ in wild-type mice and $n=7$ in Ppar $\alpha$ knockout mice. Bars without a common letter $(\mathrm{a}-\mathrm{b})$ differ, $P<0.05$.

Significant effects $(P<0.05)$ from two-way ANOVA: Fat/Cd36: litter; Fabp $p_{p m}$ : litter and litter $\times$ genotype; Fatp: litter; Lpl: litter; Fas: litter.

Ppar coactivators could have also contributed to the decreased expression of Ppar $\alpha$-regulated genes in skeletal muscle and liver during lactation. In liver, the expression of both coactivators was lower in Ppard knockout than in wild-type mice, indicating that $\operatorname{Pgc} 1 \alpha$ and $\operatorname{Pgc} 1 \beta$ are regulated by Ppar $\alpha$ in that tissue. However, in skeletal muscle, the expression of both coactivators did not differ between wild-type mice without litters and Ppara knockout mice with and without litters, suggesting that $\operatorname{Pgc} 1 \alpha$ and $\operatorname{Pgc} 1 \beta$ in skeletal muscle are regulated by Ppara independently. The finding that Ppar coactivators in skeletal muscle were not reduced in Ppard knockout mice compared with wild-type mice could provide an explanation for the observation that some Ppar $\alpha$-regulated genes, such as $m$-Cpt I and Mcad, in skeletal muscle were only slightly reduced in knockout versus wild-type mice. Reduced mRNA concentrations of Ppar coactivators in skeletal muscle of lactating wild-type mice compared with lactating Ppar $\alpha$ knockout mice could be responsible for the finding that the expression of some Ppar $\alpha$ target genes such as m-Cpt I and Mcad in skeletal muscle was even lower in lactating wild-type than in knockout mice.

Besides downregulation of fatty acid oxidation enzymes and fatty acid transporters in skeletal muscle, we observed downregulation of $U c p 3$ in skeletal muscle of lactating wild-type mice, which is consistent with recent observations in skeletal muscle and brown 


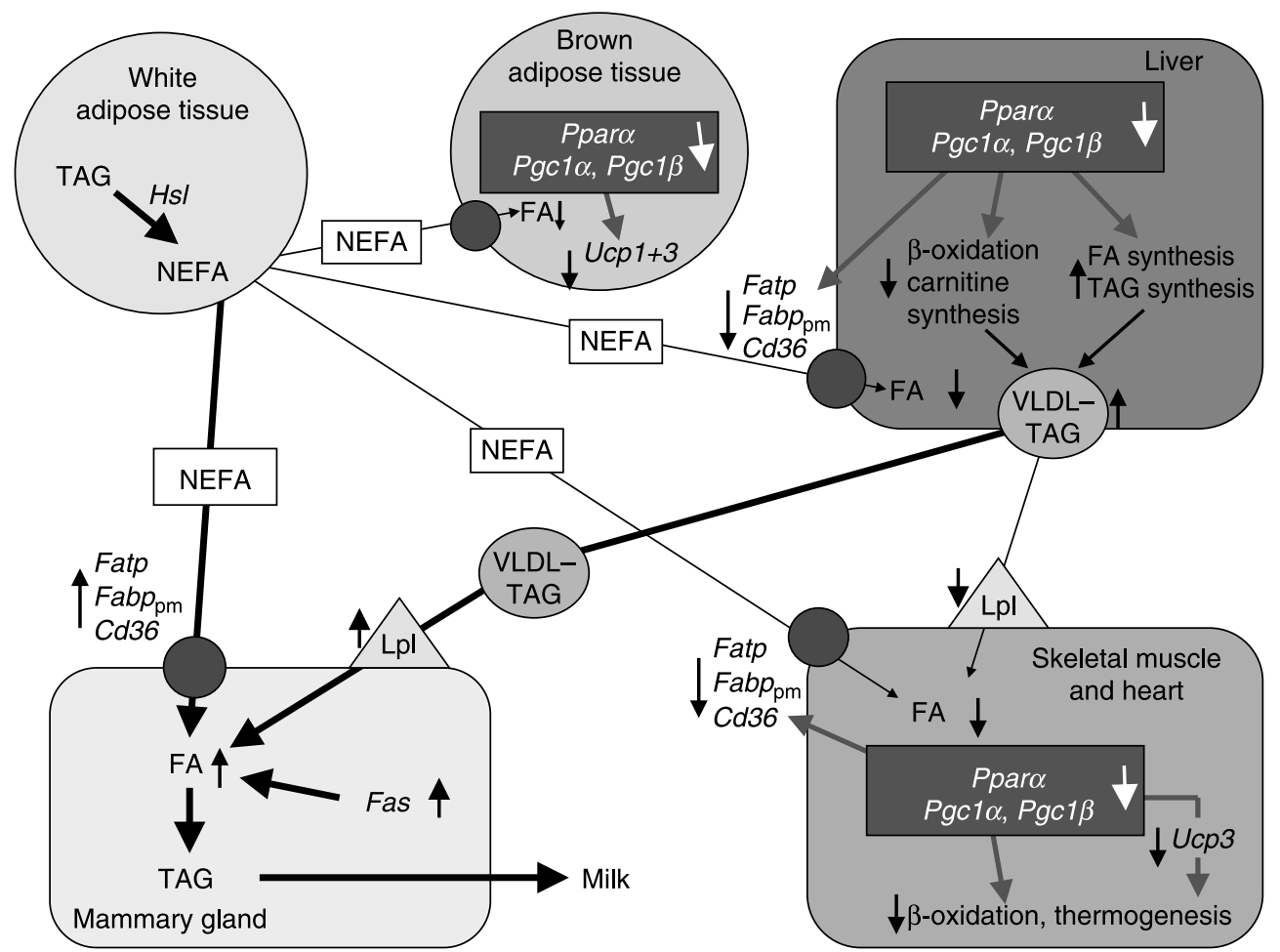

Figure 6 Working hypothesis: downregulation of Ppar $\alpha$ and its coactivators leads to a reduced uptake of fatty acids into tissues with high rates of $\beta$-oxidation, such as liver, skeletal muscle, and heart, and to a reduced rate of $\beta$-oxidation in these tissues. downregulation of Ucps in brown adipose tissue (Ucp1 and Ucp3) and skeletal muscle (Ucp3) additionally diminishes thermogenesis and oxidation of fuels, which are spared for milk synthesis. As recently shown, hepatic enzymes of carnitine synthesis are concomitantly also reduced during lactation, which, in turn, leads to a reduced carnitine content in liver and skeletal muscle (Gutgesell et al. 2009). As carnitine is involved in $\beta$-oxidation by transferring fatty acids into the mitochondrion, inhibition of carnitine synthesis can be regarded also as a means to diminish fatty acid oxidation during lactation. On the other side, synthesis of fatty acids and TAG in the liver is enhanced during lactation, leading to an increased secretion of VLDL-TAG and an increased uptake of fatty acids from VLDL-TAG into the mammary gland due to the enhanced expression of Lpl (Farid et al. 1978, Grigor et al. 1982). Simultaneously, the uptake of NEFA derived mainly from lipolysis in white adipose tissue by fatty acid transporters into the mammary gland as well as de novo fatty acid synthesis catalyzed by lipogenic enzymes including Fas in the mammary gland is increased, which also enhances the pool of fatty acids in the mammary gland available for milk TAG production. CD36/Fat, CD36/fatty acid translocase; FA, fatty acid; Fabp $p_{p m}$, plasma membrane-fatty acid-binding protein; Fas, fatty acid synthase; Fatp, fatty acid transport protein; $H s l$, hormone-sensitive lipase; $L$ pl, lipoprotein lipase; NEFA, nonesterified fatty acids; $P g c 1 \alpha / \beta$, PPAR $\gamma$ co-activator $1 \alpha / \beta$; Ppar $\alpha$, peroxisome proliferator-activated receptor $\alpha$; TAG, triacylglycerols; Ucp 1/3, uncoupling protein 1/3; VLDL, very low-density lipoprotein.

adipose tissue of lactating rats (Pedraza et al. 2000, 2001, Xiao et al. 2004a,b). Since Ucp function to uncouple the respiratory chain and, thereby, increase heat production, downregulation of $U c p$ in brown adipose tissue of rats during lactation (Pedraza et al. 2001, Xiao et al. $2004 a, b)$ has been suggested to reflect the need to conserve energy during lactation through a decrease in nonshivering thermogenesis (Williamson 1986, Pedraza et al. 2000, 2001, Xiao et al. 2004a,b). The finding that $U c p 3$ expression was reduced in skeletal muscle of lactating wild-type mice, but not in lactating Ppard knockout mice, again might indicate that the reduction of thermogenesis in skeletal muscle during lactation (Zammit 1980, Pedraza et al. 2000,
2001, Xiao et al. 2004a,b) is also mediated by the diminished expression of Ppara. Nevertheless, although $U c p 3$ has been proposed to play an important role in regulating energy expenditure and thermoregulation (Boss et al. 1997, Vidal-Puig et al. 1997), the exact physiological role of $U c p 3$ is still elusive; i.e. observations from recent studies indicate that $U c p 3$ function in skeletal muscle and heart is likely to be related to fatty acid catabolism (Muoio et al. 2002, Murray et al. 2005). In line with this assumption is the observation that $U c p 3$ participates in mitochondrial antioxidant defense and serves as an 'early response' to elevated reactive oxygen species (ROS) production and potential oxidative stress by increasing uncoupling 
respiration during prolonged exercise in rat skeletal muscle (Jiang et al. 2009). Therefore, future studies have to elucidate the exact physiological role of $U c p 3$ downregulation during lactation.

Based on the findings of this study and other studies in the literature (Trayhurn et al. 1982, Pedraza et al. 2000, 2001, Xiao et al. 2004a,b), we propose the model shown in Fig. 6. It suggests that downregulation of Ppard and its coactivators in tissues with high rates of fatty acid utilization, such as liver, skeletal muscle, and heart, and subsequently reduced utilization of fatty acids by these tissues during lactation mediates an increased flow of NEFA from white adipose tissues and TAG-rich lipoproteins into the mammary gland, and thus helps to spare energy and metabolic substrates for milk production. The physiologically increased availability of fatty acids in the mammary gland during lactation (Williamson 1986, Dewey 1997, Smith \& Grove 2002) is reflected by the marked upregulation of fatty acid transporters (Fat/Cd36 and Fatp) and Lpl, which mediate the uptake of albumin-bound NEFA and fatty acids released from TAG-rich lipoproteins respectively in the mammary gland and the reduced concentrations of NEFA (Pedraza et al. 2000) and TAG (Gutgesell $e t$ al. 2009) in plasma of lactating animals in both genotypes. In addition, expression of the lipogenic enzyme Fas, which is critical for de novo fatty acid synthesis, was strongly increased in the mammary gland of lactating mice of both genotypes. This indicates that Ppard does not play an essential role for the uptake of fatty acids into the mammary gland, and that de novo fatty acid synthesis in the mammary gland is similar in both genotypes. This indication was not unexpected as Ppard mRNA was only barely detectable in the mammary gland in the present study (data not shown) - a finding that largely confirms those of others (Gimble et al. 1998, Rodriguez-Cruz et al. 2006).

Our proposed model is supported by the finding that activation of Ppar $\alpha$ during lactation disturbs the normal metabolic adaptations during lactation. We have recently observed that activation of hepatic Ppara in the lactating rat by feeding a dietary oxidized fat, a potent activator of hepatic Ppard (Chao et al. 2001, Sülzle et al. 2004, Ringseis et al. 2007b), leads to an increased uptake of fatty acids into the liver and an enhanced $\beta$-oxidation in the liver, whereas uptake of fatty acids into the mammary gland by fatty acid transporters and $L p l$ was decreased, which, in turn, led to a dramatically reduced milk TAG content and reduced weight gains of litters during suckling (Ringseis et al. 2007a). Similar observations regarding an impairment of lactation-induced energy-sparing mechanisms by the administration of Ppara activators during lactation have been reported from others (Pedraza et al. 2000).
In conclusion, the present study shows for the first time that downregulation of Ppard, Ppar coactivators, and $P$ par $\alpha$-regulated genes, which are involved in fatty acid uptake, fatty acid oxidation, and thermogenesis, occurs only in tissues of lactating wild-type mice but not Ppara knockout mice. We postulate that downregulation of Ppard and its coactivators in tissues with high rates of fatty acid catabolism is responsible for the reduced utilization of fatty acids in liver and skeletal muscle and the reduced thermogenesis occurring in the lactating animal, which aim to conserve energy and metabolic substrates for milk production in the mammary gland. The mechanism through which Ppara is downregulated during lactation is currently unknown, but it may be speculated that hormonal changes associated with lactation, such as hyperprolactinemia or hypoleptinemia (Xiao et al. 2004a), and also changes in the levels of $\mathrm{GH}$ or insulin, might be causative. Therefore, further studies are necessary to identify the mechanisms behind the changes in Ppard expression during lactation.

\section{Declaration of interest}

The authors declare that there is no conflict of interest that could be perceived as prejudicing the impartiality of the research reported.

\section{Funding}

This research did not receive any specific grant from any funding agency in the public, commercial, or not-for-profit sector.

\section{References}

Barbera MJ, Schlüter A, Pedraza N, Iglesias R, Villaroya F \& Giralt M 2000 Peroxisome proliferator-activated receptor $\alpha$ activates transcription of the brown fat uncoupling protein-1 gene. A link between regulation of thermogenic and lipid oxidation pathways in the brown fat cell. Journal of Biological Chemistry $\mathbf{2 7 6}$ 1486-1493.

Boss O, Samec S, Paoloni-Giacobino A, Rossier C, Dulloo A, Seydoux J, Muzzin P \& Giacobino JP 1997 Uncoupling protein-3: a new member of the mitochondrial carrier family with tissue-specific expression. FEBS Letters 408 39-42.

Bruns S, Carmona MC, Mamperl T, Vinas O, Giralt M, Igleasias R \& Villaroya F 1999 Activators of peroxisome proliferators-activated receptor $\alpha$ induce the expression of the uncoupling protein- 3 gene in skeletal muscle: a potential for the lipid intake-dependent activation of uncoupling protein- 3 gene expression at birth. Diabetes 48 1217-1222.

Chao PM, Chao CY, Lin FJ \& Huang CJ 2001 Oxidized frying oil up-regulates hepatic acyl-CoA oxidase and cytochrome P450 4A1 genes in rats and activates PPAR $\alpha$. Journal of Nutrition 131 3166-3174.

Dewey KG 1997 Energy and protein requirements during lactation. Annual Review of Nutrition 17 19-36. 
Farid M, Baldwin RL, Yang YT, Osborne E \& Grichting G 1978 Effects of age, diet and lactation on lipogenesis in rat adipose, liver and mammary tissues. Journal of Nutrition 108 514-524.

Feingold KR, Wang Y, Moser A, Shigenaga JK \& Grunfeld C 2008 LPS decreases fatty acid oxidation and nuclear hormone receptors in the kidney. Journal of Lipid Research 49 2179-2187.

Gimble JM, Pighetti GM, Lerner MR, Wu X, Lightfoot SA, Brackett DJ, Darcy K \& Hollingsworth AB 1998 Expression of peroxisome proliferator activated receptor mRNA in normal and tumorigenic rodent mammary glands. Biochemical and Biophysical Research Communications 253 813-817.

Grigor MR, Geursen A, Sneyd MJ \& Warren SM 1982 Regulation of lipogenic capacity in lactating rats. Biochemical Journal 208 611-618.

Gutgesell A, Ringseis R, Brandsch C, Stangl GI, Hirche F \& Eder K 2009 Peroxisome proliferator-activated receptor $\alpha$ and enzymes of carnitine biosynthesis in the liver are down-regulated during lactation in rats. Metabolism 58 226-232.

Jiang N, Zhang G, Bo H, Qu J, Ma G, Cao D, Wen L, Liu S, Ji LL \& Zhang Y 2009 Upregulation of uncoupling protein-3 in skeletal muscle during exercise: a potential antioxidant function. Free Radical Biology and Medicine 46 138-145.

Leone TC, Weinheimer CJ \& Kelly DP 1999 A critical role for the peroxisome proliferator-activated receptor $\alpha(\operatorname{PPAR} \alpha)$ in the cellular fasting response: the PPAR $\alpha$-null mouse as a model of fatty acid oxidation disorders. PNAS 96 7473-7478.

Mandard S, Müller M \& Kersten S 2004 Peroxisome proliferator receptor $\alpha$ target genes. Cellular and Molecular Life Sciences $\mathbf{6 1}$ 393-416.

Muoio DM, MacLean PS, Lang DB, Li S, Houmard JA, Way JM, Winegar DA, Corton JC, Dohm GL \& Kraus WE 2002 Fatty acid homeostasis and induction of lipid regulatory genes in skeletal muscles of peroxisome proliferator-activated receptor (PPAR) alpha knock-out mice. Evidence for compensatory regulation by PPAR delta. Journal of Biological Chemistry 277 26089-26097.

Murray AJ, Panagia M, Hauton D, Gibbons GF \& Clarke K 2005 Plasma free fatty acids and peroxisome proliferator-activated receptor alpha in the control of myocardial uncoupling protein levels. Diabetes 54 3496-34502.

Pedraza N, Solanes G, Carmona MC, Iglesias R, Vinas O, Mampel T, Vazquez M, Giralt M \& Villarroya F 2000 Impaired expression of the uncoupling protein-3 gene in skeletal muscle during lactation: fibrates and troglitazone reverse lactation-induced downregulation of the uncoupling protein-3 gene. Diabetes 49 1224-1230.

Pedraza N, Solanes G, Iglesias R, Vazquez M, Giralt M \& Villarroya F 2001 Differential regulation of expression of genes encoding uncoupling proteins 2 and 3 in brown adipose tissue during lactation in mice. Biochemical Journal 355 105-111.

Pfaffl MW 2001 A new mathematical model for relative quantification in real-time RT-PCR. Nucleic Acids Research 29 e 45.

Reeves PG, Nielsen FH \& Fahey GC Jr 1993 AIN-93 purified diets for laboratory rodents: final report of the American Institute of Nutrition ad hoc writing committee on the reformulation of the AIN-76A rodent diet. Journal of Nutrition 123 1939-1951.

Ringseis R, Dathe C, Muschick A, Brandsch C \& Eder K 2007 a Oxidized fat reduces milk triacylglycerol concentrations by inhibiting gene expression of lipoprotein lipase and fatty acid transporters in the mammary gland of rats. Journal of Nutrition 137 2056-2061

Ringseis R, Muschick A \& Eder K $2007 b$ Dietary oxidized fat prevents ethanol-induced triacyglycerol accumulation and increases expression of PPAR $\alpha$ target genes in rat liver. Journal of Nutrition 137 $77-83$.

Ringseis R, Pösel S, Hirche F \& Eder K 2007c Treatment with pharmacological peroxisome proliferator-activated receptor $\alpha$ agonist clofibrate causes upregulation of organic cation transporter 2 in liver and small intestine of rats. Pharmacological Research $\mathbf{5 6}$ 175-183.

Rodriguez-Cruz M, Tovar AR, Palacios-Gonzalez B, Del Prado M \& Torres N 2006 Synthesis of long-chain polyunsaturated fatty acids in lactating mammary gland: role of Delta5 and Delta6 desaturases, SREBP-1, PPAR $\alpha$, and PGC-1. Journal of Lipid Research 47 553-560.

Schoonjans K, Martin G, Staels B \& Auwerx J 1997 Peroxisome proliferator-activated receptors, orphans with ligands and functions. Current Opinion in Lipidology 8 159-166.

Smith MS \& Grove KL 2002 Integration of the regulation of reproductive function and energy balance: lactation as a model. Frontiers in Neuroendocrinology 23 225-256.

Sülzle A, Hirche F \& Eder K 2004 Thermally oxidized dietary fat upregulates the expression of target genes of PPAR $\alpha$ in rat liver. Journal of Nutrition 134 1375-1383.

The UFAW Handbook on the Care and Management of Laboratory Animals 1999 The definitive work on practical husbandry, breeding, laboratory procedures and disease control for a wide variety of vertebrates from marine fish to non-human primates, edn 7. Ed TB Poole. Blackwell Science.

Trayhurn P, Douglas JB \& McGuckin MM 1982 Brown adipose tissue thermogenesis is suppressed during lactation in mice. Nature $\mathbf{2 9 8}$ 59-60.

Vidal-Puig A, Solanes G, Grujic D, Flier JS \& Lowell BB 1997 UCP3: an uncoupling protein homologue expressed preferentially and abundantly in skeletal muscle and brown adipose tissue. Biochemical and Biophysical Research Communications 235 79-82.

Whitelaw E \& Williamson DH 1977 Effects of ketogenesis from oleate or butyrate in rat hepatocytes. Biochemical Journal 164 521-528.

Williamson DH 1986 Fuel supply to brown adipose tissue. Biochemical Society Transactions 14 225-227.

Xiao XQ, Grove KL, Grayson BE \& Smith MS 2004a Inhibition of uncoupling protein expression during lactation: role of leptin. Endocrinology 145 830-838.

Xiao XQ, Grove KL \& Smith MS $2004 b$ Metabolic adaptations in skeletal muscle during lactation: complementary deoxyribonucleic acid microarray and real-time polymerase chain reaction analysis of gene expression. Endocrinology 145 5344-5354.

Young ME, Patil S, Ying J, Depre C, Ahuja HS, Shipley GL, Stepkowski SM, Davies PJ \& Taegtmeyer H 2001 Uncoupling protein 3 transcription is regulated by peroxisome proliferator-activated receptor $\alpha$ in the adult rodent heart. FASEB Journal 15 833-845.

Yu S \& Reddy JK 2007 Transcription coactivators for peroxisome proliferator-activated receptors. Biochimica et Biophysica Acta $\mathbf{1 7 7 1}$ 936-951.

Zammit VA 1980 The effect of glucagons treatment and starvation of virgin and lactating rats on the rates of oxidation of octanoyl-Lcarnitine and octanoate by isolated liver mitochondria. Biochemical Journal 190 293-300.

Received in final form 8 June 2009

Accepted 3 July 2009

Made available online as an Accepted Preprint 3 July 2009 